https://doi.org/10.31261/IJREL.2021.7.1.08

\title{
Hanne-Lore Bobáková
}

School of Business Administration, Silesian University in Opava, Czech Republic https://orcid.org/0000-0003-3875-3596

\section{Martina Chylková}

School of Business Administration, Silesian University in Opava, Czech Republic https://orcid.org/0000-0003-4954-4263

\section{The Use of Online Education by the Czech Population in the European Context}

\begin{abstract}
The article deals with online educational courses in the Czech Republic. The subject of the investigation is the participation of individuals between 16-74 years of age in online education in the Czech Republic and its development. The investigation also focuses on the computer skills of individuals and their development between 2005-2014, and also in 2017, depending on data availability. All the above-mentioned indicators were analysed and compared to the situation in the neighbouring countries and in the European context. The methods of analysis, synthesis and comparison were applied. The research showed that the number of individuals participating in courses in the Czech Republic was relatively low in comparison to other neighbouring countries, even though the advancement of computer skills in the Czech Republic was constantly increasing from 2005 to 2014 .

K e y w or d s: competence, computer skill, internet skill, online education, sociability
\end{abstract}


Our society is in the middle of the times of the rapid development of information technology. Computer Assisted Learning (CAL) belongs to fast developing activities. It has been used in both formal and informal education in the form of eLearning. It reflects a certain ability to become a part of an online society. A prerequisite for joining this society is the knowledge of relevant competencies and computer skills and, as van Deursen and van Dijk (2010) stated, internet skills should be considered vital assets. According to Zlatuška (1999), the transition to this information society might create uncertainty and social tensions. Therefore strengthening the information society also means considering educational and educational-political aspects.

Currently, the global society has found itself in a situation which has affected countries in various sectors due to the coronavirus pandemic. The effects of the pandemic were also seen in the educational sphere, when educational institutions were looking for the ways not to interrupt the educational process via the various types of information telecommunication technology. In this situation, it is appropriate to investigate the state of competencies and computer skills in the Czech Republic.

\section{Research Literature on the Subject}

Foreign literature in this field comprises a variety of topics. This article tackles e.g. the issue of digitization that affects our thinking and communication with the world (Baecker, 2017; Castells, 2004), and didactic works focusing on media didactics enabling the development of online education (Kerres, 2018a). Kerres (2018b) and Zavera (2019) draw attention to the new educational needs in the digital environment. The following table provides an overview of the development of media pedagogy in the $20^{\text {th }}$ and $21^{\text {st }}$ centuries (Table 1).

The research literature on the topic is quite extensive and the research topics are diverse. Pastore (2002) discusses the challenges of eLearning and the role of eLearning in education. O'Neill, Singh and O'Donoghue (2004) examine infrastructural and pedagogical aspects of eLearning with reflections on the usefulness of technology to improve the learning experience. Singh, O'Donoghue and Worton (2005) address the issue of the implementation of eLearning into university education, including the structure and delivery of university education. They observe a variety of implications for students and teachers from a global perspective. Regarding the Czech milieu, web courses are dealt with by e.g. Zounek and Sudický (2012), Černý $(2017,2018 a)$ and others. 
The Use of Online Education by the Czech Population in the European Context

Table 1

Media pedagogy in 20th and 21st centuries

\begin{tabular}{|c|c|c|}
\hline Media pedagogy & $20^{\text {th }}$ century & $21^{\text {st }}$ century \\
\hline Challenge & $\begin{array}{l}\text { Mass media (press, radio, } \\
\text { television) are used passively } \\
\text { in leisure time }\end{array}$ & Digitization penetrates society \\
\hline Educational process & Influenced by a book & Influenced by digitization \\
\hline Approach & $\begin{array}{l}\text { Active media work, } \\
\text { extracurricular youth work }\end{array}$ & $\begin{array}{l}\text { Interactive media concepts } \\
\text { in formal and non-formal } \\
\text { education, strengthening of } \\
\text { non-formal education }\end{array}$ \\
\hline Goals & $\begin{array}{l}\text { Media competence } \\
\text { development: } \\
\text { - media criticism, } \\
\text { - specialization media, } \\
\text { - media use, } \\
\text { - creation of media. }\end{array}$ & $\begin{array}{l}\text { Education in the digital world } \\
\text { - knowledge of digital } \\
\text { technology, } \\
\text { - creating an attitude to } \\
\text { knowledge about culture, } \\
\text { - identity development, } \\
\text { - coping with professional } \\
\text { requirements, } \\
\text { - participation in social } \\
\text { conversation }\end{array}$ \\
\hline Political conflicts & $\begin{array}{l}\text { National press } \\
\text { Media concerns influence } \\
\text { opinion on education }\end{array}$ & $\begin{array}{l}\text { Multinational technology and In- } \\
\text { ternet corporations are influenc- } \\
\text { ing the private sphere. Technol- } \\
\text { ogy is becoming an actor. }\end{array}$ \\
\hline
\end{tabular}

S o u r c e: Own work, based on Kerres (2018a).

For example, Černý (2018a) describes and analyzes the use of Google Analytics and Smartlook to examine the educational environment of online courses. The monograph by Černý (2017) is a contextual description of the information and learning society with its pros and cons. Zounek and Sudický (2012) provide an overview of online education in their book eLearning - learning with online technologies, which also summarizes the importance of learning in life, the significance of learning and eLearning theories, and the position of technology in education, its advantages and disadvantages in connection with didactic questions of online course preparation.

From the latest literature, Conrad (2020), who examines the supportive effects of learning in the use of modern technologies only if there is a match between the individual assumptions of students, media characteristics and methodological use, could be mentioned. Balkan (2020) addresses the question of how new media can influence foreign language teaching. Hamdi (2020) also deals with the issue of new media in foreign language teaching from the viewpoint of didactics. Neugebauer (2020) pays attention to the future of teachers at a time of new media develop- 
ment. The completion of an academic degree via modern technologies is also the subject of scientific research (cf., e.g. Rohs \& Weber (2020)). The latest monograph in this area provides an overview of the new trending technologies (Opfermann et al., 2020). We would also like to point out a monograph that examines the role of digital education in improving digital competencies with both teachers and students (Abrah et al., 2020).

\section{Terminology}

Černý defines sociability as the ability and competence to enter into relationships in a society. He distinguishes five areas of digital competencies:

- information and data literacy,

- cooperation and communication,

- creation of digital objects,

- security,

- the ability to solve problems.

In the article, we understand the term sociability in the same way as Černý (2018b, p. 149), namely, as the ability of a society to behave in an online environment based on the availability of special skills that enable the production of communication within this environment. However, we are focused here on the part of digital competencies referred to by Černý as 'information and data literacy'.

Online learning and eLearning are concepts which are differentiated from each other. Online learning is referred to as Internet learning, while eLearning is meaningfully linked to institutional education (Černý, 2018a, p. 148). The definitions of eLearning are heterogeneous (Zounek, Staudková, Juhaňák, \& Poláček, 2016). Černý (2018a, p. 148) prefers the term "online learning", justifying it with the important philosophical, pedagogical, social and technical changes that have accompanied education in the last decade. For Černý, the distinction between online learning and eLearning is also important because they distinguish between institutional and non-institutional education. As Fojtík (2001) states, eLearning, in the broader sense, is classical teaching supported by computer technology. In a narrower sense, it is presented by a virtual school. According to Marešová (2009, p. 39), modern educational systems (Learning management systems - LMS) are becoming a personalized virtual learning environment in which a student can discover courses taught by instructors or professors, tests, instructions on how to study, but, also, he/she can participate in discussion forums with teachers and other students as well.

From a specific perspective, this article tackles the sociability of the Czech population in the online environment and it is compared with the general concept of online sociability in the European context. The term sociability, in accordance with Černý (2018a, p. 150), is understood as a skill or ability to engage in society, 
cooperate and communicate. It is quite evident that the ability to engage in society today also involves engaging in cyberspace.

Sociability in the online environment is a topical issue and it is defined from different points of view. Hence, the article will investigate the topic of sociability in online education and computer skills in the online space.

\section{Research Subject, Goal and Methods}

The subject of this research is the participation of individuals aged 16-74 in online education in the Czech Republic and its development between 2007-2017. Furthermore, the research focuses on the computer skills of individuals in the Czech Republic in 2005, 2007 and 2014. The article is based on the data obtained from the Czech Statistical Office. The sample is made up of the following files:

1. Data set of individuals aged 17-74 who attended an online training course between 2007 and 2017 in \%.

2. Data set of individuals with 1 or 2 computer skills in 2005, 2006 and 2014.

3. Data set of individuals with 3 or 4 computer skills in 2005, 2006 and 2014.

4. Data set of individuals with 5 or 6 computer skills in 2005, 2006 and 2014.

All four files are based on the data from the Czech Statistical Office, which was available.

The studied individuals are people who attended an online course in the last three months prior to the research.

The aim of the research is to find out:

- How the participation of individuals in online training courses changed between 2007-2017,

- How computer skills management developed in the online environment in 2005, 2007 and 2014.

The level of internet skills was judged based on the respondents' self-evaluation, without testing or examining the knowledge. The respondents were asked about their specific activities on the Internet, namely:

- the use of a search engine for information searching,

- sending and receiving electronic mail,

- chatting,

- posting messages to information forums,

- internet telephony,

- the use of peer-to-peer networks to exchange movies, music or video,

- creating a personal website,

- copying, moving files/folders,

- copying/inserting data within a document,

- basic spreadsheet calculations, 
- compressing/zipping files,

- connecting new devices,

- using the programming language to create programs.

The methods of analysis, synthesis and comparison were applied in the research.

\section{Results of Research}

The participation of individuals aged 16-74 in online education courses expressed in percentages were the focus of this study.

In 2007, only 1 percent of individuals in the Czech Republic attended online education courses. Comparing with our neighbours, only Slovakia and Austria had the same percentage; other countries, such as Hungary and Germany, showed participation in online learning activities by 1 percentage point higher. Participation did not increase in the following years, 2009 and 2010 but it went up in 2011. Between 2011 and 2017, participation in online training courses increased threefold and amounted to $3 \%$.

The numbers of participants in online education are higher in Poland, Hungary, Slovakia, Germany, and Austria in comparison to the Czech Republic. From these countries, Germany, with $6 \%$, achieved the highest participation rate of individuals in training courses, followed by Austria, with 5\%. The following table summarizes the data:

Table 2

The participation of individuals aged 16-74 in online education courses in $\%^{1}$

\begin{tabular}{lccccccccc}
\hline Country & 2007 & 2008 & 2009 & 2010 & 2011 & 2013 & 2015 & 2016 & 2017 \\
\hline Czechia & 1 & 2 & 1 & 1 & 3 & 3 & 3 & 3 & 3 \\
Poland & -2 & 2 & 1 & 2 & 2 & -2 & 3 & 4 & 4 \\
Hungary & 2 & 2 & 2 & 3 & 5 & 4 & 3 & 4 & 4 \\
Slovakia & 1 & 1 & 1 & 1 & 1 & 4 & 3 & 3 & 4 \\
Germany & 2 & 2 & 3 & 3 & 4 & 4 & 4 & 5 & 6 \\
Austria & 1 & $\mathrm{u}^{3}$ & 1 & 2 & 3 & 3 & 4 & 4 & 5 \\
\hline
\end{tabular}

S ou r c e: Own work

Note: 1 - Individuals who attended an online course in the last three months prior to the research, $\mathbf{2}$-not available, $\mathbf{3}$ - unreliable or uncertain data. 
The Use of Online Education by the Czech Population in the European Context

\section{Individuals with 1 or 2 Internet skills}

The level of Internet skills was judged based on the respondents' self-evaluation, without testing or examining the knowledge. The respondents were asked about their specific activities on the Internet, namely:

- the use of a search engine for information searching,

- sending and receiving electronic mail,

- chatting,

- posting messages to information forums,

- internet telephony,

- the use of peer-to-peer networks to exchange movies, music or video,

- creating their own website.

The overview below shows the individuals who reported one or two activities. Data for the Czech Republic in 2005 is not available. In 2006, 16\% of individuals said they had 1 to 2 internet skills. In 2014, this figure was 18\%. It can be seen that the highest increase in acquired Internet skills was in Hungary. From $7 \%$ in 2005, the number of individuals reached $18 \%$ in 2014.

A decline in acquired internet skills can be seen in Poland, from 19\% in 2005 to $16 \%$ in 2006 and $14 \%$ in 2014 . There was a drop in these skills in Germany as well, with $23 \%$ in 2005 and $17 \%$ in 2006; in 2014, this number went up slightly to $18 \%$. Slovakia, with $20 \%$ of individuals with 1 or 2 internet skills in 2014 , had the highest result. The following table summarizes the data:

Table 3

Individuals with 1 or 2 Internet skills in \%

\begin{tabular}{lccc}
\hline \multicolumn{1}{c}{ Country } & 2005 & 2006 & 2014 \\
\hline Czechia & $-{ }^{1}$ & 16 & 18 \\
Poland & 19 & 16 & 14 \\
Hungary & 7 & 9 & 18 \\
Slovakia & 17 & 18 & 20 \\
Germany & 23 & 17 & 18 \\
Austria & 12 & 12 & 15 \\
\hline
\end{tabular}

S o u r c e: Own work based on the Czech Statistical Office

Note: 1 - Not available.

\section{Individuals with 3 or 4 Internet skills}

The level of internet skills focused on the same skills as mentioned in the previous part.

Data on individuals who had mastered 3 or 4 Internet skills in 2005 is not available for the Czech Republic. There was an increase in skills from 22\% in 2006 to 
$23 \%$ in 2014. The fewest individuals who mastered 3 or 4 skills were detected in Hungary. In 2005, the majority of individuals who had mastered 3 or 4 internet skills was identified in Slovakia (35\%) and Germany (34\%). In 2014, the number decreased to $32 \%$ in Slovakia and to $31 \%$ in Germany. The following table illustrates this development:

Table 4

Individuals with 3 or 4 Internet skills in \%

\begin{tabular}{lccc}
\hline \multicolumn{1}{c}{ Country } & 2005 & 2006 & 2014 \\
\hline Czechia & -1 & 22 & 23 \\
Poland & 22 & 18 & 23 \\
Hungary & 16 & 21 & 26 \\
Slovakia & 35 & 30 & 32 \\
Germany & 34 & 31 & 31 \\
Austria & 26 & 24 & 29 \\
\hline
\end{tabular}

S o u r c e: Own work based on the Czech Statistical Office

Note: 1 - Not available.

\section{Individuals with 5 or 6 Internet skills}

The level of internet skills is judged based on the respondents' self-evaluation, without testing or examining the knowledge. The respondents were asked about their specific activities on the Internet, namely:

- copying, moving files/folders,

- copying/inserting data within a document,

- basic spreadsheet calculations,

- compressing/zipping files,

- connecting new devices,

- using the programming language to create programs.

In 2005, Austria showed the highest number of individuals who had mastered 5 or 6 internet skills, with 31\%. The data was not available in the Czech Republic. In the Czech Republic, there was an increase in the number of individuals who had mastered 5 to 6 internet skills from 14\% in 2006 to 27\% in 2014. Only Germany, with $30 \%$, and Austria, with $34 \%$, achieved better results than the Czech Republic. The lowest result, 21\%, was noted in Poland in 2014. 
The Use of Online Education by the Czech Population in the European Context

Table 5

Individuals with 5 or 6 Internet skills in \%

\begin{tabular}{lccc}
\hline \multicolumn{1}{c}{ Country } & 2005 & 2006 & 2014 \\
\hline Czechia & $-{ }^{1}$ & 14 & 27 \\
Poland & 13 & 11 & 21 \\
Hungary & 20 & 25 & 24 \\
Slovakia & 19 & 17 & 25 \\
Germany & 22 & 27 & 30 \\
Austria & 31 & 31 & 34 \\
\hline
\end{tabular}

S o u r c e: Own work based on the Czech Statistical Office

Note: 1 - Not available.

\section{Discussion}

According to the obtained data, the Czech Republic is one of the countries whose population participates in very few online educational courses. Other countries, such as Bulgaria, Croatia, Cyprus, Austria, Portugal, Romania, and Slovakia, also achieved the same results expressed in percentages in 2007. The highest percentages of people who took online courses were in Finland (13\%), Iceland (9\%), Estonia (7\%), and Latvia (6\%) in the same year.

In 2017, Finland did not maintain its lead in the number of individuals who had attended online courses in the last three months. Iceland came in first that year (20\%). It was followed by Sweden (18\%) and Norway (14\%). The Czech Republic did not achieve a significant increase that year. With 3 percent, it represented almost the lowest position in this indicator. Only Bulgaria (2\%) and Croatia (2\%) noted worse results. Romania had the same percentage as the Czech Republic.

In the Czech Republic, the number of individuals who had mastered 1 or 2 internet skills increased slightly from 16\% to 18\% between 2006 and 2017. With this result, Czechia reached the same position as Germany and Hungary, with this percentage increasing in Hungary and falling from $23 \%$ in 2006 to $18 \%$ in 2017 in Germany. The results in Poland (14\%) and Austria (15\%) were worse than in the Czech Republic. Conversely, the results in Slovakia were higher, with 20\%.

In 2014, the Czech Republic performed worse than the neighbouring countries in terms of mastering 3 or 4 internet skills, which was similar to the situation in Poland. Germany, on the other hand, achieved the highest results among the neighbouring countries (31\%). 
Comparing the criterion of mastering 5 to 6 internet skills, the Czech Republic was in the third place (with 27\%), after Germany (with 30\%) and Austria (with $34 \%$ ) in 2014. Compared to other European countries, the Czech Republic lagged behind Finland (46\%), Norway (42\%), Luxembourg (42\%), Denmark (39\%), and Sweden (38\%) in mastering these internet skills. It is gratifying for the Czech Republic that the number of individuals mastering 5 to 6 internet skills is rising.

\section{Conclusions}

Technological development affects many sectors and has a huge potential for education, as it makes it possible to change society in a global environment and give its members access to education. There has been some development in education as regards information technology. It concerns both participation of individuals in online training courses and the level of skills of those individuals. It turned out that literacy in this area was growing and the number of individuals who had mastered 5 to 6 skills was increasing in the Czech Republic, namely copying, moving files/ folders, copying/inserting data within a document, basic spreadsheet calculations, compressing/zipping files, connecting new devices, and using a programming language to create programmes.

The Internet has unprecedented potential, especially in ways of making education accessible. This aspect represents a huge potential for development in the competencies of the population in individual countries, which will have a distinct impact on the education and economic development of a given country.

The question is how behavioural contexts can affect the inclusion of individuals in online learning activities. Age, gender, education, income, social status, etc., as determinants, can bridge the digital divide and lead to the development of lifelong learning for individuals. The state of online education in the Czech Republic shows that online educational activities thus have a relatively great potential for further growth.

Digital media may play a major role in the educational system in the future due to their multimedia nature. The combination of text, graphics, video and audio is a tool for creating methodological and didactic concepts in their use in teaching. However, it should be realized that the learning outcome depends on many other factors in the individual processing in the learning process, which are especially motivational and emotional in nature. 
The Use of Online Education by the Czech Population in the European Context

The authors teach business English and German, and communication at the Department of Tourism and Leisure Activities at Silesian University in Opava, School of Business Administration in Karvina.

\section{References}

Abrah, L. D. Q. J., \& Al-Zudaidy, A. H. A. (2020). Die Rolle der digitalen Bildung für die Verbesserung der digitalen Kompetenzen von Lehrer/Innen und Lernenden im Fremdsprachenunterricht. Lark journal for philosophy, linguistics and social sciences, 37(2), 473-482.

Baecker, D. (2017). Wie verändert die Digitalisierung unser Denken und unseren Umgang mit der Welt? Handel 4.0 (pp. 3-24). Berlin, Heidelberg: Springer Gabler.

Balkan, F. (2020). Der Einsatz von neuen Medien im DaF-Unterricht eine kontrastive und semiotische Analyse von der Verwendung multimedialer Hilfsmittel im Rahmen neues Lernenneues Handeln. (Dissertation). Hacettepe UniversitätInstitut für SozialwissenschaftAbteilung für Deutsche Sprache und Literatur.

Castells, M. (2004). Die Internet-Galaxie: Internet, Wirtschaft und Gesellschaft. Wiesbaden: Verlag für Sozialwissenschaften.

Conrad, M. (2020). Emotionen und Wissenserwerb im computergestützten Unterricht. Emotionales Erleben und Wissenserwerb im computergestützten Wirtschaftsunterricht (pp. 9-72). Wiesbaden: Springer Gabler.

Černý, M. (2017). Informační a učící se společnost. Brno: Paido.

Černý, M. (2018a). Využití nástrojů webové analytiky pro pochopení učení v online prostředí. ProInflow, 10(1), 49-67. doi:doi.org/10.5817/ProIn2018-1-4

Černý, M. (2018b). Vybrané př́ístupy k učení se od druhých v online prostředí. ProInflow, 10(1), 147-166. doi: 10.5817/ProIn2018-2-8.

Fojtík, R. (2001, March 9) Co znamená e-learning. Česká škola. Retrieved from http://www.ceskaskola.cz/ICTveskole/Ar.asp?ARI=2345\& CAI=2129\&EXPS=\%22NEBOJME*\%22\%22E -LEARNING\%22

Hamdi, K. (2020). Medieneinsatz im DaF-Unterricht in Algerien. Ein effizientes Mittel zur Förderung der Ausspracheschulung (Doctoral dissertation). Université d'Oran2 Mohamed ben Ahmed.

Kerres, M. (2018a). Mediendidaktik. Konzeption und Entwicklung mediengestützter Lernangebote. Berlin: De Gruyter Oldenbourg.

Kerres, M. (2018b, April). Bildung in der digitalen Welt: Wir haben die Wahl. Denk-doch-mal.de Das online-Magazin. Retrieved from http://denk-doch-mal.de/wp/michael-kerres-bildung-inder-digitalen-welt-wir-haben-die-wahl/

Marešová, H. (2009). E-learning in the multi-user virtual environment. Journal of Technology and Information Education, 1(1), 39.

Neugebauer, J. (2020). Die Zukunft der Lehrkraft: Lehren mit neuen Medien in der Erwachsenenund Altenbildung. BoD - Books on Demand.

O’Neill, K., Singh, G., \& O’Donoghue, J. (2004). Implementing eLearning programmes for higher education: A review of the literature. Journal of Information Technology Education: Research, 3(1), 313-323. 
Opfermann, M., Höffler T. N., \& Schmeck, A. (2020). Lernen mit Medien: ein Überblick. Handbuch Bildungstechnologie (pp. 17-30). Berlin, Heidelberg: Springer.

Pastore, R. (Ed.). (2002). E-learning in Education: An Overview. Willis, D., Price, J., \& Davis, N., ed. Proceedings of SITE 2002--Society for Information Technology \& Teacher Education International Conference. USA: Association for the Advancement of Computing in Education (AACE).

Rohs, M. \& Weber, C. (2020). Digitale Medien in der wissenschaftlichen Weiterbildung. Handbuch Wissenschaftliche Weiterbildung (pp. 455-478). Wiesbaden: Springer VS.

Singh, G., O’Donoghue J., \& Worton, h. (2005). A Study Into The Effects Of eLearning On Higher Education. Journal of University Teaching \& Learning Practice. 2(1). https://ro.uow.edu.au/ jutlp/vol2/iss1/3

Van Deursen, A., \& Van Dijk, J. (2010). Internet skills and the digital divide. New Media and Society, 13, 893-911. doi:10.1177/1461444810386774

Zavera, I. C. (2019). The analysis of the response from tertiary education programs to the challenges of the Fourth Industrial Revolution. Proceedings of the International conference on Business Excellence, 13, 1261-1266. https:/doi.org/10.2478/picbe-2019-0111

Zounke, J., Juhaňák, L., Staudková, H., \& Poláček, J. (2016). E-learning. Učení (se) s digitálními technologiemi. Praha: Wolters Kluwer.

Zounek, J., \& Sudický, P. (2012). Učení (se) s online technologiemi. Praha: Wolters Kluwer.

Zlatuška, J. (1999). Informační společnosti a Česká republika. Universitas. Revue Masarykovy univerzity v Brně, 3, 3-9.

Hanne-Lore Bobáková, Martina Chylková

\title{
Korzystanie ze zdalnego nauczania w czeskiej populacji w kontekście europejskim
}

\author{
Streszczenie
}

Artykuł poświęcony jest zdalnym kursom edukacyjnym w Republice Czeskiej. Przedmiotem dociekań jest udział osób w wieku 16-74 lat w zdalnym kształceniu w Czechach oraz jego rozwój w latach 2007-2017. Badanie skupia się również na umiejętnościach komputerowych poszczególnych osób i ich rozwoju w roku 2005, 2007 i 2014. Wszystkie wyżej wymienione wskaźniki są analizowane i porównywane z sytuacją w krajach sąsiadujących oraz w kontekście europejskim. Zastosowano metody analizy, syntezy i porównania. Badania wykazały, że liczba osób uczestniczących w zdalnych kursach w Republice Czeskiej jest stosunkowo niska w porównaniu z innymi krajami sąsiadującymi, pomimo że w latach 2005-2014 stale rosła kontrola nad umiejętnościami komputerowymi w Republice Czeskiej.

S łow a k lu c z ow e: kompetencja, umiejętności komputerowe, umiejętności internetowe, edukacja online, komunikatywność 
The Use of Online Education by the Czech Population in the European Context

Ханне-Лоре Бобакова, Мартина Чилкова

\title{
Использование интернета в образовательных целях в Чехии и в европейском контексте
}

\begin{abstract}
А н нот а ция
В статье рассматриваются образовательные онлайн-курсы в Чехии. Предметом исследования является онлайн-образование для людей в возрасте 16-74 лет в Чешской Республике и его развитие в 2007-2017 годах. В фокусе исследования - компьютерные навыки людей и их развитие в 2005, 2007 и 2014 годах. Все вышеперечисленные показатели анализируются и сравниваются с ситуацией в соседних странах и в европейском контексте. Применялись методы анализа, синтеза и сравнения. Исследование показало, что количество обучающихся на курсах в Чешской Республике относительно невелико по сравнению с соседними странами, не смотря на то, что уровень контроля за компьютерными навыками в Чехии постоянно усиливался с 2005 по 2014 год.
\end{abstract}

К л ю ч е в ы е с л о в а: компетенция, компьютерные навыки, Интернет-навыки, онлайн образование, коммуникативность

Hanne-Lore Bobáková, Martina Chylková

\section{El Uso de Enseñanza Online en la Población Checa y en el Marco del Contexto Europeo}

\author{
Resumen
}

El artículo trata sobre los cursos de educación online en la República Checa. El tema de la investigación es la participación de personas en la educación en línea a la edad de 16 a 74 años en la República Checa y su desarrollo entre 2007-2017. La investigación también se centra en las competencias informáticas de las personas y su desarrollo en 2005, 2007 y 2014. Todos los indicadores mencionados anteriormente están siendo analizados y comparados con la situación en los países vecinos y en el contexto europeo. Se aplicaron los métodos de análisis, síntesis y comparación. La investigación mostró que el número de personas que participan en cursos en la República Checa es relativamente bajo en comparación con otros países vecinos, a pesar de que el control de las habilidades informáticas en la República Checa aumentó constantemente entre 2005 y 2014.

P a labra s c lave: competencia, habilidad en computación, habilidad en internet, educación en línea, sociabilidad 